\title{
NOT ALL EMOTICONS ARE CREATED EQUAL
}

\author{
Francisco Yus* \\ University of Alicante \\ Alicante, Spain
}

\begin{abstract}
Text deformation and emoticon use have become pervasive in today's computermediated communication. In this article, emoticons are analysed from a pragmatic, relevance-theoretic perspective, which entails determining the extent to which emoticons contribute to the eventual relevance of the information communicated by the text typed on the keyboard. Eight pragmatic functions are proposed, which correspond to the different ways in which emoticons satisfy the user's search for relevance. The analysis will also address how emoticons contribute to a more fine-grained identification of the user's attitudes, feelings and emotions, which are often difficult to pin down in text-based communication.
\end{abstract}

Keywords: Emoticons. Text deformation. Cyberpragmatics. Oralisation.

\section{TEXT DEFORMATION, EMOTICONS, AND INTERNET-MEDIATED COMMUNICATION}

Text deformation (e.g. creative use of punctuation marks, repetition of letters or strategic use of capitalisation) and emoticons (or smileys) are typical in Internetmediated communication in both asynchronous messages (e.g. comments to entries on Facebook) and synchronous text-based interactions (e.g. Facebook chat and instant messaging on the mobile phone). These discursive strategies aim at producing a string of text rich enough to direct the recipient not only towards (supposedly) the intended interpretation of the message, but also towards an identification and measurement of the underlying propositional attitudes, affective attitudes, feelings and emotions attached to the message when it is typed on the computer keyboard (YUS, 2005). Indeed, the repertoire of words available in one's language is limited for communicating the full range of feelings, emotions and attitudes that can be experienced while interacting on the Net (what I call funnel effect). As Fussell and Moss (1998) state, the conventional affective lexicon does not suffice for expressing the nuances of specific emotional experiences. Many affective terms are used loosely and therefore may not have the precision speakers desire. Faced with this limitation, users tend to resort to text deformation (also called oralized written text in YUS, 2001, 2010, 2011) and emoticons in order to ensure a more adequate coding (and the addressee user's eventual inference) of this non-propositional information.

\footnotetext{
* Senior lecturer at the Department of English Studies at University of Alicante, Spain. PhD in Linguistics, Pragmatics at University of Alicante, Spain. E-mail: francisco.yus@ua.es.
} 
Emoticons were initially compositions of letters that iconically look like facial expressions (after turning one's head 90 $)$. These are defined by Danesi $(2009$, p. 110) as:

strings of keyboard characters that, when viewed sideways (or in some other orientation), can be seen to suggest a face expressing a particular emotion. An emoticon is often used in an e-mail message or newsgroup posting as a comment on the text that accompanies it. Common emoticons include the smiley :-) or :) and the winkey ;-) and the yawn :-O, among others.

Nowadays, on the contrary, many galleries of fully iconic faces are offered by the different interfaces for virtual interactions, including animated emoticons with "flash technology." This supplementary level of iconicity may actually alter the way the underlying feelings or emotions are interpreted and reacted upon, compared to traditional text-based emoticons (see 2.3 below).

In this article, eight functions of emoticons are proposed which focus on their pragmatic quality, that is, on the role that they play both in the eventual (in)correct interpretation of the text to which they are attached and also in the (in)adequate identification of the user's feelings, attitudes and emotions, as coded by these emoticons, while the user is typing the message. Before that, in section 2 several issues concerning emoticons are addressed, since these have pragmatic implications affecting the quality of their interpretation.

The examples provided throughout this article come from emoticon-filled entries posted by six of my Spanish Facebook friends (translations will be provided), together with the emoticons found in the comments that these entries aroused, in a period of 12 months (July-December 2012 and July-December 2013).

\section{ISSUES CONCERNING EMOTICON USE 2.1 INTENTIONALITY}

Everyday gestures and facial expressions may be intentional and acquire an ostensive status leading to a specific interpretation (i.e. to the interlocutor's acknowledgement of their role in the eventual interpretation of the utterance, as happens when a wink warns about an intended ironic interpretation, for instance). Gestures and facial expressions may also be unintentional, exuded, given off beyond the person's control (e.g. blushing). Finally, speakers can act upon initially unintended gestures and turn them into fully ostensive acts (i.e. a quality of acts in which the speaker draws the interlocutor's attention and directs it to his/her intentions, see Sperber and Wilson, 1995). The combination of intentionality (or the lack of it) and the quality of understanding leads to a number of interesting cases. In Yus (2011, p. 167) I proposed a list/taxonomy of instances (2a-f) arising from the (apparently) simple nonverbal behaviour in (1): 
(1) [During A's visit, the host - B - yawns].

(2) a. B yawns intentionally so that A infers that B wants him to leave; A interprets the ostensive act correctly and decides to leave.

b. B yawns intentionally so that A infers that B wants him to leave; A interprets the ostensive act as a signal that $\mathrm{B}$ is tired, i.e. A thinks that there is no underlying intention in the yawning.

c. B yawns intentionally so that A infers that B wants him to leave; A correctly interprets the act as ostensive, but chooses a different interpretation, for example that $\mathrm{B}$ is trying to communicate that $\mathrm{A}$ is very boring.

d. B yawns because she is tired, without any intention in its production; A interprets correctly both the behaviour as unintentional and its interpretation (tiredness).

e. B yawns because she is tired, without any intention in its production; A interprets correctly the behaviour as unintentional but chooses a different interpretation, for example boredom instead of tiredness.

f. B yawns because she is tired, without any intention in its production; A incorrectly interprets the act as ostensive and connotes it with an intentionality that B does not hold.

After reading Wharton $(2009$, p. 32), I realised that there is one further possibility, namely ( $2 \mathrm{~g}$ ), since (as I have already mentioned) it is also possible to generate a nonverbal behaviour unintentionally and then intentionally act upon it so as to make it more manifest to the interlocutor and create specific expectations of relevance (which may then be correctly or incorrectly understood):

(2) g. B yawns because she is tired, without any intention in its production; since she is so tired, B decides to draw A's attention to this signal of tiredness (intentionally), making it possible for A to infer not only that she is tired, but also that she is tired enough to want A to leave.

Since emoticons are typed, only (2a) and (2c) are, in theory, possible. This stress on intentionality does not entail that users invariably have a specific interpretation in mind when they type an emoticon (or select it from a gallery of graphic/animated ones). On the one hand, users may have a wide array of feelings and emotions when they decide to code them in the shape of an emoticon, and readers may ascribe multiple feelings and emotions when faced with an emoticon attached to a verbal message. In general, although emoticons are used more consciously than actual nonverbal behaviour, and there is more control over the message that a person wants to convey (DERKS et al., 2008a, p. 380), speakers are often bad at assessing their own feelings and emotions, at least in a fine-grained way, they are unable to control and explain the range and scope of the information that exudes from their interactional behaviour, and are even worse at putting these feelings and emotions into coded signs such as emoticons. Very often, then, users encode (and infer) broad positive/negative emotions when they use (and interpret) an emoticon. 
On the other hand, emoticons are frequently used simply for generating a colourful visual arrangement of the text (especially in chat rooms, where the user can choose from lots of emoticons in colour and even select colours for text) so that the message typed "stands out from the textual crowd" and arouses an interest in the other users.

\subsection{REDUNDANCY}

In previous research (YUS, 2010, 2011), I pictured the possibility of emoticons being mainly redundant, as in "I feel great today :-)," in which the emoticon seems to add no further meaning to what is said verbally. However, emoticons are typed with an expectation of relevance. Their readers are pushed into supplementary mental effort to determine the feeling or emotion that underlies the emoticon and to work out its relationship to what has been typed verbally. This extra effort has to be offset with additional interest (cognitive effects, in relevance-theoretic terminology), and the eight pragmatic functions that will be proposed below are evidence of interesting communicative roles beyond redundancy, especially when combined with textual input. In Wiseman (2013, p. 29), for example, there are quotes by young mobile users which indicate that both text deformation and emoticon use can radically alter the eventual interpretation of the message:

Dre Gambrell (18 years old): "You can tell what she wants pretty much by how she texts. The dry 'Hey' is O.K. But then there's some that have the 'Heyyy' with the extra y's and the winky face, and that means this conversation could possibly go somewhere. They're probably the hooking-up type."

Ian Davis (19 years old): "When I see a smiley face, it's the opening of the doorway to emotions. That first emoticon is significant. When it comes, it means something."

Although some researchers have underestimated the role of emoticons (e.g. WALTHER; D'ADDARIO, 2001), many authors have stressed that emoticons are not redundant and, in fact, provide relevant additional information that aids in the eventual relevance of the message that was typed. Jibril $(2013$, p. 203) concludes that "emoticons and punctuation marks have tremendous effects on how people perceive and interpret messages." Huang et al. (2008, p. 466) also noticed that users exhibit more "enjoyment, personal interaction, perceived information richness, and perceived usefulness" when interacting in emoticon-laden virtual conversations. Tossell et al. (2012, p. 660) suggest that emoticons play a similar role to nonverbal behaviour in face-to-face interactions. Besides, the inclusion of emoticons helps readers "better understand the level and direction of the emotional context surrounding the message relayed over the internet." Lo (2008) and Luor et al. (2010, p. 891) comment that when Internet users are faced with text without emoticons, most of them cannot perceive the correct emotion, attitude, and intent of the sender. On the contrary, the combination of visual cues and text does create a more positive attitude than text alone. Fullwood and Martino (2007) focussed on how emoticon use affects participant evaluations of extroversion and agreeableness. They concluded that the online chat partner was regarded as more extrovert and more 
agreeable when emoticons were used in conversation. Finally, Derks et al. (2007, p. 843) emphasize how emoticons "enhance the exchange of social information by providing additional social cues beyond what is found in the text of a message."

2.3 ICONICITY

Emoticons are iconic, in the sense that they visually resemble facial expressions, to a greater or lesser extent. They have traditionally been created by using letters and punctuation marks (as in [;-D], but nowadays "graphic emoticons" (the ones with full facial display and even animated quality) are the norm, to the extent that in many interfaces, if one types a typical sequence for creating an emoticon (e.g. typing “;” + "_" + ")" in succession), a fully iconic, graphic emoticon is automatically created. This increasingly iconic quality of emoticons may alter the way the information that they communicate is interpreted by the reader. But are underlying emotions easier to identify when they are coded as fully iconic emoticons?

In a recent article, Churches et al. (2014) claim that text-based emoticons are interpreted just like faces even though the reader has to turn his/her head $90^{\circ}$ to actually spot the facial resemblance. It is common sense to assume that fully iconic graphic emoticons will be processed even more like a face, given the greater resemblance. The emotions tied to facial expressions should also be easier to spot (GANSTER et al., 2012, p. 229). In this sense, Yuasa et al. (2011) showed how these graphic emoticons activate the area used in emotional discrimination and also the area that is typically activated when seeing a human face, although to a lesser degree. Finally, the eventual relevance of the overall message (verbal content plus emoticon) should also increase due to a lowering of mental effort needed to ascribe meaning to the graphic emoticon.

\subsection{TRANS-INTERFACE CHOICE}

Beyond typographic emoticons (the traditional ones made up of letters and punctuation marks), interfaces for interactions on the Net usually offer their own galleries of emoticons to choose from. WhatsApp galleries differ enormously from the ones found on Facebook or on chat rooms. However, applications for these interfaces are also found in tablets and mobile phones, which have their own keyboards with emoticons (e.g. emoji ones). As a consequence, interfaces such as Facebook get "intoxicated" with emoticons not provided by the interface but by the device itself. This phenomenon may have implications on how conventionalized the use of emoticons is in the different interfaces, and on their eventual interpretation.

\subsection{LACK OF EMOTIONAL GRADATION}

One of the aims in Yus (2005) was to check to what extent users were capable of distinguishing degrees in the intensity of the feelings and emotions communicated from a parallel amount of text deformation and emoticons, often involving creative modification of the core emoticons in order to communicate additional connotations 
(PARK et al., 2013). The expression ad hoc measurement was proposed for the receiver's inferential attribution of attitudinal and emotional emphasis of textual deformation and emoticons. Firstly, this attribution is ad hoc because the users have to evaluate, in a very specific interactive context, the extent and quality of these textual deformations. And secondly, it also involves some kind of measurement, since we can in theory establish a continuum of textual deformations intimately related to the intensity of the attitudes and emotions that users intend to communicate. The hypothesis was, therefore, that users inferred a greater intensity in the user's feelings and emotions when a greater amount of text was typed. That is, that the reader infers a greater intensity of the feeling in (3c) and (4c) than in (3a) and (4a) due to a higher amount of text deformation:

(3) a. hello everyone.

b. heeeeelo eeeeeveryooone.

c. heeeeellooooooo eeeeeeeeeveryooooone

(4) a. :-)

b. :-())))

c. :-(-)))))))

A survey was given out to university and high school students to check this hypothesis and the results yielded an interesting conclusion: that the inference of feelings and emotions in virtual conversations is a "black or white" phenomenon, not a graded one. The informants did find a supplementary intensity of the feelings typed in (3c) and (4c) compared to (3a) and (4a), but found no difference of intensity between (3b) and (3c) or between (4b) and (4c). In short, any additional amount of text deformation added is regarded as conveying further intensity of the emotion, but no levels of text deformation are correlated to levels of emotional intensity. There is a "higher than default" layer of information but, beyond this point, users seem to be unable to relate a higher quantity of deformation to a higher intensity in the emotion felt while typing the message.

\subsection{NEED OF TEXTUAL "ANCHORAGE”}

Users have no problem identifying the most widely used emoticons such as [:-)], [;-)] or [:-(]. But the arrangement of these iconic textual constructions may become really complicated and even culture-specific, to the extent that many emoticons may be misunderstood (even non-understood) without the aid of the propositional information provided by the text to which these emoticons are attached. As claimed in Yus (2011, p. 169 ), in the use of emoticons there is a continuum from the purely arbitrary to the explicitly iconic based on cultural rules for making sense of visual signs. These rules are shared by the community, i.e. they are mutually manifest to all its members. In the case of the emoticon, it demands some kind of emoticonic literacy from the users beyond the simplest well-known compositions. Normally, as concluded in Garrison et al. (2011, p. 120 ), users draw on similar types of emoticons (a small set) and use them in particular places within the utterance. 
Therefore, it is very likely that the authors of the emoticons in (5) will not obtain the desired effect without the aid of the information of the message that precedes them, which "anchors" their meanings, in Barthes' (1977) sense, thereby reducing the range of possible interpretations that these emoticons can convey:

(5) a. You know I don't agree :-e

b. I've recently been ill with a cold :-'I

c. Did you miss me? >:-> (malicious comment)

\subsection{MULTIPLE AUDIENCES}

Emoticons are suitable for certain audiences in certain informal contexts and not advisable in formal or academic settings. It comes as no surprise that emoticons are known to be used more frequently in socio-emotional contexts than in task-oriented ones (DERKS et al., 2007, 2008b). Users have more control of when and with whom they are using emoticons when they engage in synchronous conversations. As commented upon in Yus (forthcoming), the problem lies in the emoticons within asynchronous entries on social networking sites such as Facebook, since these entries are addressed to a very generic category of friends, a label which covers heterogeneous audiences that entail the use of specific degrees of (in)formality, different registers, (in)appropriate topics, etc. This is what Marwick and Boyd (2010) call "context collapse." Entries on Facebook end up being a sort of repository of information of heterogeneous quality and similar heterogeneous audiences, some of which may not consider the use of emoticons appropriate.

\section{A NEW TAXONOMY OF PRAGMATIC FUNCTIONS OF EMOTICONS}

Several authors have proposed a variety of functions of emoticons according to different criteria. Some of them are listed below:

1. (a) Emotion indicators, mapped directly onto facial expression; (b) indicators of non-emotional meanings, mapped conventionally onto facial expressions; and (c) illocutionary force indicators that do not map conventionally onto a facial expression (DRESNER; HERRING, 2012, p. 62).

2. (a) Additions of para-verbal elements to the message; (b) expressing redundancy; (c) acting as antiphrasis (when emoticons are used to contradict or annul the verbally expressed meaning); (d) acting as an entire turn (when emoticons serve the purpose of an entire message); and (e) functioning as syntactic markers (often serving as punctuation) (AMAGHLOBELI, 2012, p. 352-353).

3. (a) Expressing emotion; (b) enhancing the verbal part of the message (acting as a supporting emoticon); and (c) expressing humour (LUOR et al., 2010, p. 890).

4. (a) As devices of modesty; (b) as hedging devices; (c) to soften requests; (d) as positive politeness strategies; (e) in rapport building; (f) humour; (g) to help convey emotion, humanize online interaction; (h) emphatic use; and (i) lexical use (KAVANAGH, 2010). 
5. (a) Evaluative function (the addition of an emoticon allows others to interpret the meaning of an utterance); (b) to express politeness and friendliness; and (c) as backchannel devices (e.g. to give feedback) (WALDNER, 2009, p. 35).

6. (a) Expressing emotion; (b) strengthening the message; (c) regulating the interaction; and (d) putting into perspective (DERKS et al., 2008a, p. 386).

7. (a) Accentuating or emphasizing a tone or meaning of the message; (b) establishing the current mood or impression of the sender; and (c) making the otherwise completely textual conversation creative and visually salient (XU, 2007).

The functions of emoticons that we are interested in from a pragmatic, relevancetheoretic approach are the ones that, to a greater or lesser extent, underline their role in contributing to the eventual relevance of the text they accompany. In other words, the functions of emoticons that arouse interest for a relevance-theoretic perspective are the ones in which the emoticons lead to (or at least aim at) a more fine-grained interpretation of the coded verbal message that follows/precedes them in terms of underlying attitudes, feelings and emotions. Sometimes, the emoticon will achieve relevance by reducing the user's mental effort in determining which attitude, feeling of emotion the sender intends to communicate, sometimes even changing the overall meaning of the propositional content completely. On other occasions, interpreting the emoticon will demand extra effort from the user, but this effort will be compensated for by an offset of additional interest (cognitive effects) derived from a more adequate and accurate interpretation of the message achieved. In the next headings, eight possible pragmatic functions will be provided.

\subsection{TO SIGNAL THE PROPOSITIONAL ATTITUDE THAT UNDERLIES THE UTTERANCE AND WHICH WOULD BE DIFFICULT TO IDENTIFY WITHOUT THE AID OF THE EMOTICON}

Propositional attitudes are important for successful interactions, since they introduce an additional metarepresentational level of information beyond the explicit content of the utterance. These attitudes are related to a variety of mental experiences, such as emotional reactions, feelings, and judgements, which may be consciously or unconsciously held by the speaker towards the utterance itself (AHERN, 2010, p. 149).

As exemplified in Yus (2005, p. 151), natural languages offer speakers a whole range of linguistic means which can be used in the coding of propositional attitudes. These include that-clauses introduced by an attitudinal verb, as in (6a), parenthetical clauses (6b), verbal moods (6c), illocutionary adverbials (6d), and evidentials (6e), among others:

(6) a. I regret that you failed your exam.

b. It's time to go, I guess.

c. Come here right now!

d. Frankly, I am not surprised.

e. No doubt, he is the best candidate for the job. 
On a number of occasions, though, the underlying attitude (and also the feelings or emotions attached to the utterance) can only be derived from non-linguistic evidence, by focussing on vocal (e.g. intonation) and visual (e.g. facial gestures) aspects of the specific context in which the act of communication is taking place, and this is where emoticons may play a clarifying role.

On paper, attitudes seem to be cognitively more lasting than emotions, even though one can temporarily hold a certain attitude to what one is saying (propositional attitude) or feeling (affective attitude). As pointed out by Pilkington (2000, p. 152-153),

\begin{abstract}
An emotion, such as fear or anger, is a temporary state, a response to some perceived event or state of affairs in the world... An attitude, such as love or hate, involves the storage of a belief and/or phenomenal state in long-term memory, attached to a conceptual address... Whereas an emotion is a temporary response to a situation involving the creation of a new desire or the strengthening of an existing desire, an attitude is focussed upon a particular object.
\end{abstract}

Internet users are also expected to embed the propositional form of their messages in a particular attitude under which the utterance is typed. Nevertheless, on the Internet the interlocutor's attitude is often not clearly (or not sufficiently) "visible" (i.e. textually made explicit, for example, with a 'that-clause' introduced by an attitudinal verb) since users sometimes resort to textual deformation and emoticon use in order to favour an adequate attitudinal identification. Indeed, sometimes users either do not have time to type all the text which would make the interpretation of their propositional attitude much easier to identify, or are simply unsatisfied with the verbal options available to communicate both the attitude and its intensity. When faced with these limitations, the user will tend to resort to textual deformation and emoticons in order to fulfil this communicative task, thus facilitating the reader's identification of an appropriate attitudinal schema, and also a parallel ad hoc measurement of the intensity of this attitude (YUS, 2005, p. 162).

In this first function, the emoticon makes it easier to identify the propositional attitude which would otherwise be difficult to spot. Consider (7):

(7) Yo no tengo tiempo de aburrirme, ni de leer :((

[I have no time to get bored, nor to read:([].

Que toquen en martes no nos facilita las cosas :, (

[The fact that they are playing on a Tuesday, doesn't make things easier :,(].

Aquí no hay fingers, y mira q los he buscado :-(

[There are no fingers here, and I looked for them everywhere :-(].

In all of these cases, the user regrets that she has no time to get bored, that the band is playing on Tuesday and that there are no fingers, but the identification of this attitude is made possible with the aid of the emoticon, otherwise the attitude could have been one of mere assertion. This use is similar to the one found in face-to-face interactions, where certain aspects of the speaker's attitude are most often expressed through non-linguistic or paralinguistic cues (AHERN, 2010, p. 150). 
In this case, the user does resort to a linguistic means to communicate his/her propositional attitude (as in (6) above) and the emoticon achieves relevance by adding an additional level of intensity in the way this attitude is held, as in (8) below:

(8) Espero que siempre os acordéis de mis lecciones de español :-)

[I hope you'll always remember my Spanish lessons :-)].

\subsection{TO STRENGTHEN/MITIGATE THE ILLOCUTIONARY FORCE OF A SPEECH ACT}

Emoticons may also achieve relevance by enhancing or softening the illocutionary force of speech acts (e.g. directives) and thus communicating a more adequate extent of the impact that the user intends with his/her words (DRESNER; HERRING, 2010, 2012; LUOR et al., 2010, p. 890). The mitigating function is more frequent than the strengthening one in the samples analysed. Dresner and Herring (2012, p. 64-66) suggest these examples:

(9) a. I would like a non-circumventing solution;->

b. I am very sensitive and cry easily, and gets even worse when I feel awful :)

In (9a), the winking emoticon indicates that the message should not be taken as a request or a demand, as its form ("I would like") otherwise suggests. Instead, its function is to downgrade the utterance to a less face-threatening speech act, a simple assertion. The invalidation of the request/demand interpretation that has been taken on board as the user reads the message takes more processing effort but, at the same time, offers additional cognitive effects in directing the reader to the exact quality of the speech act. In (9b), the emoticon mitigates what otherwise looks like a self-pitying list of complaints, suggesting that the interpretation is not that of complaining, but rather asserting or describing. Again, this directing the reader to the specific extent of the underlying intention is relevant even if the reader has to alter the interpretation held so far until the emoticon turns up. Other examples are provided below:

(10) a. Interesados mandadme primero privado! ;-)

[Those interested send me a private message first ;-)].

b. Carlos leelo YA!!! Te va a encantar :-)

[Carlos read it now! You'll love it :-)].

c. ¡Deja de escribir sobre mí! ¡Estás obsesionada! XDDDDDD

[Stop writing about me! You're obsessed! XDDDDDD]. 
In (10a), the emoticon softens the impact of the imperative and downgrades its illocutionary force as a directive, turning it into an invitation to be sent a private message. (10b) exhibits typical strategies of text deformation (use of capital letters and punctuation marks), which make the directive even stronger. The user then adds an emoticon so as to mitigate the impact of the directive. Something similar happens in (10c), in which the directive is softened to the extent that the eventual interpretation is closer to a joke (function 4 below) than to a directive speech act.

\subsection{TO CONTRADICT THE EXPLICIT CONTENT OF THE UTTERANCE (A): JOKING}

An important role of emoticons is to signal that the user should not be understood literally, but that the underlying intention is to joke about some state of affairs, and therefore the propositional attitude is not that of endorsement but of humorous dissociation. The relevance of the emoticon lies in its capability to direct the reader away from a literal interpretation of the utterance and, instead, to offer him/her interpretive reward in terms of generation of humorous effects. A couple of examples are given in (11):

(11) a. [Text commenting on a photo of a shop with the same name as the addreseee user].

No sabía que tenías una tienda en Alicante :)))))) Besos...

[I didn't know you had a shop in Alicante :)))))). Kisses...].

b. Happy Birthday my friend!!! pareces un colegial que va a entrar en el colegio, creo que debes tener un cuadro en tu casa en plan Dorian Gray ;)

[...you look like a schoolboy who is about to enter the school, but I think you must have a Dorian Gray kind of picture at home].

In (11a), the user adds an emoticon to make it clear that he does not intend the addressee to interpret him literally. The same applies to $(11 \mathrm{~b})$, in which the user jokes about the addressee's look by providing an utterly false statement.

\subsection{TO CONTRADICT THE EXPLICIT CONTENT OF THE UTTERANCE (B): IRONY}

A similar case to joking involves contradicting propositional content due to an ironic intention. The main difference with jokes is the explicit dissociative attitude that irony exhibits. During interpretation, some information from context is inconsistent with the explicit interpretation of the utterance, which triggers a search for the underlying ironic attitude. Spotting the attitude as dissociative is essential to differentiate irony from other types of incongruity such as the one in jokes (YUS, 2009). Besides, the relevance of ironic communication often lies in foregrounding the existence of some information which is shared, and successful communication makes both interlocutors fully aware of this mutuality. This strengthening of shared information is facilitated by the use of the emoticon. Consider the examples in (12): 
(12) a. User 1: le daria a no me gusta si se pudiera.. jeje

User 2: Jajajaj User 1, en el fondo yo sé que te gustan :-)

[I would click on "don't like" if I could.. hehe].

[Hahaha User 1, I know that, deep down inside you, you like them :-)].

b. Que vida mas dura $\mathrm{xD}$

[What a hard life you lead $x D]$.

c. User 1: Estas escenas me suenan... no se por qué... :-)

User 2: ¿Ah, sí? Pues no sé yo tampoco por qué te sonarán ;-)

[These scenes ring a bell, don't know why... :-)].

[Really? Well, I don't know why they do, either ;-)].

d. Eso lo aclara todo. Gracias, no podía respirar con normalidad por la incertidumbre... :-D

[This clarifies it all. Thanks. I couldn't breathe normally because of the uncertainty... :-D].

In (12a), User 2 knows that User 1 dislikes the content of the entry, but pretends that he does like it; by using the emoticon, she makes it clear (ironically) that both agree on the quality of the content (this quality is mutually manifest to both of them, using a relevance-theoretic terminology). (10b) is a typical example of irony in which the user dissociates herself from the explicit content of the utterance and communicates the opposite while, at the same time, foregrounding the real quality of the addressee's life. In (12c), both users know which scenes are being talked about, but pretend that they do not; the outcome is more awareness of the mutuality of this information. Finally, in (12d) the user is unsatisfied with the other user's reply and stresses that by using an ironic statement with the aid of the emoticon.

\subsection{TO ADD A FEELING OR EMOTION TOWARDS THE PROPOSITIONAL CONTENT OF THE UTTERANCE (AFFECTIVE ATTITUDE TOWARDS THE UTTERANCE)}

Feelings and emotions (and the affective attitudes attached to utterances) are different from propositional attitudes, but the dividing line is often blurred. Cowie (2000), for instance, acknowledges that there is a difficult boundary between emotion terms and terms that refer to an attitude. Since attitude entails a categorisation of a stimulus along an evaluative dimension, and evaluation is regarded as a fundamental dimension of emotionality, there is a certain overlap between attitudes and emotions. Similarly, as Wichmann (2000) points out, the kind of labels we associate with a propositional attitude reflect the emotions aroused by that opinion, belief or knowledge. The labels associated with the expression of propositional attitude seem therefore to be related to those associated with feelings and emotions. Caffi and Janney (1994, p. 327) distinguish between feelings (a broad, complex class of subjective personal sensations or states of inner physiological arousal), emotions (a restricted subset of empirically investigable phenomena within this general category that are relatively transitory, of a certain intensity, and are attached to, or triggered by, particular objects, ideas, or outer incentive events), moods (of longer duration than emotions and not necessarily attached to specific inner states or definite objects), and attitudes (transitory feeling states with partly uncontrollable subconscious psychobiological components and partly controllable expressive components, which are said to be instrumental in maintaining social and psychological equilibrium and adapting to different situations). 
In general, as commented upon in Yus (2005), users want to let other users know about their emotional states while engaging in virtual conversations. Since emotions are typically displayed without much control on the Internet (e.g. flaming, trolling), textual deformation and emoticons are good for communicating their emotions, favouring not only a better identification, but also an adequate assessment of their intensity. Besides, as was mentioned above, the range of vocal and visual options interlocutors have to type their emotions is limited compared to the vast amount of subtleties and shades of meanings that emotions can acquire (the aforementioned funnel effect). For instance, Fussell (2002) points out that although nonverbal cues can indicate what general class of emotions a person is feeling, they typically do not provide very detailed information about that person's emotional state. Textual deformation and emoticons would then be seen as an attempt to signal explicitly the approximate extent of a range of emotions which are difficult to verbalize.

This sixth function refers to occurrences in which the user shows, with the aid of emoticons, a certain feeling or emotion towards the content of the utterance, and therefore differs from the next type, which is focussed on feelings and emotions towards the communicative act itself or emotions in parallel to the production of the message, rather than towards the content to the message. These are some examples:

(13) a. Siii voy a estar en Cáceres así que nos vemos !!! :-) :-) :-) Aquí te estoy esperando ya!!! Un besito enooorme.

[Yes, I'll be in Cáceres, so we'll meet !!! :-) :-) :-) I am here waiting for you already!!! Big kiss].

b. Sábado en casa :-)

[Saturday at home :-)].

c. En Badajoz, nació sobrina :-) !!!

[In Badajoz, my niece was born :-) !!!]

d. El reencuentro se acercaaaaa :-)

[The reunion is approaching :-)].

All of the examples exhibit a positive emotion (happiness) that the users feel towards the explicit information that is provided by the propositional content of the utterances. In (13a) the user is happy that they will meet. In (13b) the user is happy to stay at home on a Saturday. In (13c) the user is happy that her niece has been born. And in (13d) the user is happy at the prospect of an imminent reunion. All of the examples refer to emotions that are felt towards the content of the utterances (while the next function refers, rather, to feelings and emotions in parallel to the utterance, as will be explained below).

\subsection{TO ADD A FEELING OR EMOTION TOWARDS THE COMMUNICATIVE ACT (FEELING OR EMOTION IN PARALLEL TO THE COMMUNICATIVE ACT)}

In face-to-face interactions, nonverbal communication plays different roles. One of them is to show the feeling or emotion that the speakers feel towards the propositional content of what they are uttering. Sometimes, though, nonverbal 
behaviour has a more social connotation (the typical quality of phatic exchanges), in which the speakers show what the act of communicating or interacting is making them feel, and hence the nonverbal behaviour is produced in parallel to the verbal content, thereby connoting the communicative act, rather than qualifying the propositional content being typed. On the Internet, we find similar instances of this role of nonverbal communication, this time with the aid of text deformation and emoticons. For example, the excessive textual deformation and emoticon use that young users resort to when complimenting someone who has posted a new photo aims at reproducing the same situation in face-to-face communication, where friends also exaggerate their nonverbal behaviour when it comes to complimenting. Example (14) is proposed in Yus (forthcoming):

(14) User 1: que guapa!!!peazo fiestas que te pegas, no paras!!!! :-)

[How pretty!!! Some parties, uh! You never stop!!!! :-)].

User 2: La próxima t aviso a ver si te animas!!! :-)

[Next time, I'll give you the heads up in case you feel like coming!!! :-)].

In (14), User 2 is not using the emoticon because she is happy to let User 1 know about a future party, or happy to ask whether User 1 will be willing to go. Instead, she is showing the kind of nonverbal behaviour that is aroused by the fact that she is communicating with User 2, by the prospect of getting User 1 to join her in the party, and in general by the emotions that she feels while she is typing that message for User 1 (including a feeling of bonding or enhanced friendship), rather than towards the content of the message itself. Besides, the message needs inferencing so as to be turned into a fully propositional and relevant explicature. The development of User 2's message would be as follows:

(15) a. Contextualized proposition (via inferential enrichment):

Next time [that I go to a party] I'll give you the heads up in case you feel like coming [there with me].

b. Proposition plus propositional attitude:

[I inform you that / I promise you that] Next time [that I go to a party] I'll give you the heads up in case you feel like coming [there with me].

c. Proposition plus propositional attitude plus affective attitude (towards the communicative act):

[I am happy to tell you that*] [I inform you that / I promise you that] Next time [that I go to a party] I'll give you the heads up in case you feel like coming [there with me] [and I insist on your coming with $\left.m e^{* *}\right]$.

* Communicated by the emoticon.

** Communicated by the repetition of the exclamation mark.

Vandergriff (2014) also cites an example that fits this seventh function of emoticons:

(16) User 1: Wish we had more time to chat!

User 2: Me too :( Take care, and bye!

YUS, Francisco. Not all emoticons are created equal. Linguagem em (Dis)curso - LemD, Tubarão, SC, v. 14, n. 
In (16), as Vandergriff (ibid.) correctly states, "the emoticon becomes a social cue, much like a smile in face-to-face exchanges, showing pleasure with the encounter." User 2 is showing that the fact that they have no more time to chat makes him/her unhappy.

Several authors have also stressed the social role of emoticons beyond their propositional role, the fact that they can mirror what usually happens in face-to-face interactions when interlocutors use nonverbal behaviour to enhance the act of communication or the social connotation beyond qualifying the propositional content itself (JIBRIL, 2013, p. 203; DERKS et al., 2008b, p. 778). Ahern (2010, p. 150) is right in pointing out that emotional states are not necessarily always related to the content of an utterance: they may just reflect the way the speaker feels at the utterance time without holding a close relation to what is being said. In these instances, it seems to be more important to show a bond with the interlocutor, a sharing of parallel emotions than to show an emotion towards the actual propositional content of the message. The same applies to examples such as the ones listed in (17):

(17) a. M puedes decir q comes para estar cada vez mas wapa????? ;-)

[Can you tell what you eat to get prettier and prettier??????;-)].

b. :-( quiero volver....

[:-( I want to come back....].

c. Pues ya sabes que estás invitada!!!! ;-)

[You now know you're invited!!!! ;-)].

d. [Beber sidra es] una de las mejores cosas de ir a un congreso a Oviedo...;-)

[[Drinking cider] is one of the best things of attending a Conference in Oviedo...,-)].

e. He organizado un congreso internacional... Mucho trabajo :-)

[I've organized an international Conference... Lots of work :-)].

In (17a), the user is showing joy (with a shade of envy) while complimenting her friend, and smiles (with an emoticon) in the same way as she would smile if she said that to her in a face-to-face scenario, in which a bonding of friendship results from this complimenting speech act. In (17b), the user is not sad that she wants to come back; on the contrary, she does want to come back and the emoticon shows the feeling she has while typing the message, perhaps underlining how much she misses being with the interlocutor. In (17c), the user shows happiness at the bonding of friendship stemming out of this invitation, and also at the future attendance to the party. By smiling, the user stresses the friendship with the interlocutor and shows that this bond makes her happy too. In (17d), the user says that she is happy to be in Oviedo drinking cider; hence this joy is not related to the utterance but to the activity in Oviedo, a parallel emotion while typing the message. Finally, the user in (17e) does not expect us to interpret that she is happy to have lots of work; instead, she communicates an emotion in parallel to this activity: despite the amount of work, she is actually happy to organize this Conference. 
Finally, with a similar role to function 2 above, emoticons can also be used for enhancing the intensity of a feeling or emotion which has already been coded verbally in the message. Some examples are provided in (18), where the emotions conveyed by the words in italics are enhanced by the addition of an emoticon:

(18) a. Esta va por mi hermana y por los bailes ochenteros, nos encantan :-)

[This is on my sister and the dances of the 80s, we love them :-)].

b. No me gusta, me rechifla! Me has emocionado, amiga :-)

[I don't like it, I love it! You've really moved me, my friend :-)].

c. Oleeee olee olee!! que ganas de conocer a la pequeñaa :-)

[Oleeee olee olee!! look forward to meeting the little baby :-)].

d. Sounds great!! So excited to see you!! :-)

e. Me ha alegrado ver esto al despertarme... :-)

[I was pleased to see that after waking up... :-)].

The examples in (18) are the ones that were typically regarded to be redundant in previous research (YUS, 2010, 2011). However, these emoticons are not neutral but contribute to the eventual relevance of the message. They generate extra cognitive effects related to a more fine-grained interpretation of the extent and intensity of the emotions that the user is feeling at the time of typing these messages.

\section{CONCLUDING REMARKS}

Emoticons are not redundant or irrelevant. On the contrary, they play a wide range of possible roles or functions that aid in making the accompanying text more relevant to the addressee user. In this paper eight pragmatic functions of emoticons have been suggested: (a) to signal the propositional attitude that underlies the utterance and which would be difficult to identify without the aid of the emoticon; (b) to communicate a higher intensity of a propositional attitude which has already been coded verbally; (c) to strengthen/mitigate the illocutionary force of a speech act; (d) to contradict the explicit content of the utterance by means of joking; (e) to contradict the explicit content of the utterance by means of irony; (f) to add a feeling or emotion towards the propositional content of the utterance (affective attitude towards the utterance); (g) to add a feeling or emotion towards the communicative act (feeling or emotion in parallel to the communicative act); and (h) to communicate the intensity of a feeling or emotion that has already been coded verbally.

In all of these functions, emoticons play interesting roles that make the texts communicated on the Net a little closer to the actual feelings, emotions and attitudes that the user holds while typing them, and hence these emoticons make typed utterances less prone to eventual misunderstandings. In relevance-theoretic terminology, emoticons make manifest a number of assumptions concerning the user's attitudes, 
feelings and emotions that complement, enhance, and even contradict the text to which these emoticons are attached. Therefore, their usefulness in directing the reader towards the most relevant interpretation should not be underestimated.

\section{REFERENCES}

AHERN, A. Speaker Attitude in Relevance Theory: An Overview. In: WALASZEWSKA, E.; KISIELEWSKA-KRYSIUK, M.; PISKORSKA, A. (Eds.). In the Mind and Across Minds. Newcastleupon-Tyne: Cambridge Scholars Publishing, 2010. p. 147-166.

AMAGHLOBELI, N. Linguistic Features of Typographic Emoticons in SMS Discourse. Theory and Practice in Language Studies, v. 2, n. 2, p. 348-354, 2012.

BARTHES, R. Image-Music-Text. London: Fontana, 1977.

CAFFI, C.; JANNEY, R.W. Toward a Pragmatics of Emotive Communication. Journal of Pragmatics, v. 22, p. 325-373, 1994.

CHURCHES, O.; NICHOLLS, M.; THIESSEN, M.; KOHLER, M.; KEAGE, H. Emoticons in Mind: An Event-Related Potential Study. Social Neuroscience, v. 9, n. 2, p. 196-202, 2014.

COWIE, R. Describing the Emotional States Expressed in Speech. In: Isca Workshop (ITRW) on Speech and Emotion: A Conceptual Framework for Research. Belfast: The Queen's University, September, 2000.

DANESI, M. Dictionary of Media and Communications. New York and London: M. E. Sharpe, 2009.

DERKS, D.; BOS, A.E.R.; VON GRUMBKOW, J. Emoticons and Social Interaction on the Internet: The Importance of Social Context. Computers in Human Behavior, v. 23, p. 842-849, 2007.

Emoticons and Online Message Interpretation. Social Science Computer Review, v. 26, n. 3, p. 379-388, 2008a.

DERKS, D.; FISCHER, A. H.; BOS, A. E. The Role of Emotion in Computer-Mediated Communication: A review. Computers in Human Behavior, v. 24, p. 766-785, 2008 b.

DRESNER, E.; HERRING, S.C. Functions of the Non-Verbal in CMC: Emoticons and Illocutionary force. Communication Theory, v. 20, n. 3, p. 249-268, 2010.

Emoticons and Illocutionary Force. In: RIESENFEL; SCARAFILE, G. (Eds.). Philosophical Dialogue: Writings in honor of Marcelo Dascal. London: College Publication, 2012. p. 59-70.

FULLWOOD, C.; MARTINO, O. I. Emoticons and Impression Formation. Applied Semiotics, v. 19, 2007.

FUSSELL, S.R. The Verbal Communication of Emotion: Introduction and Overview. In: FUSSELL, S.R. (Ed.). The verbal Communication of Emotion: Interdisciplinary Perspectives. Mahwah: Lawrence Erlbaum Associates, 2002. p. 1-22.

GANSTER, T.; EIMLER, S.C.; KRÄMER, N.C. Same but Different!? The Differential Influence of Smilies and Emoticons on Person Perception. Cyberpsychology, Behavior, and Social Networking, v. 15, n. 4, p. 226-230, 2012.

GARRISON, A.; REMLEY , D.; THOMAS, P.; WIERSZEWSKI, E. Conventional Faces: Emoticons in Instant Messaging Discourse. Computers and Composition, v. 28, p. 112-125, 2011.

HUANG, A. H.; YEN, D. C.; Zhang, X. Exploring the Potential Effects of emotIcons. Information \& Management, v. 45, p. 466-473, 2008.

JIBRIL, T. A.; ABDULLAH, M. H. Relevance of Emoticons in Computer-Mediated Communication Contexts: An Overview. Asian Social Science, v. 9, n. 4, p. 201-207, 2013.

KAVANAGH, B. A Cross-Cultural Analysis of Japanese and English Non-Verbal Online

Communication: The Use of Emoticons in Weblogs. Intercultural Communication Studies, v. XIX, n. 3, p. $65-80,2010$.

LO, S.-K. The Nonverbal Communication Functions of Emoticons in Computer-Mediated Communication. Cyberpsychology \& Behavior, v. 11, n. 5, p. 595-597, 2008.

LUOR, T.; WU, L.; LU, H.-P.; TAO, Y.-H. The Effect of Emoticons in Simplex and Complex TaskOriented Communication: An Empirical Study of Instant Messaging. Computers in Human Behavior, v. 26, p. 889-895, 2010. 
MARWICK, A. E.; BOYD, D. I Tweet Honestly, I Tweet Passionately: Twitter users, Context Collapse, and the Imagined Audience. New Media \& Society, v. 13, n. 1, p. 114-133, 2010.

PARK, J.; BARASH, V.; FINK, C.; CHA, M. Emoticon Style: Interpreting Differences in Emoticons Across Cultures. In: ICWSM'13, 2013.

PILKINGTON, A. Poetic effects. A Relevance Theory Perspective. Amsterdam: John Benjamins, 2000. SPERBER, D.; WILSON, D. Relevance: Communication and Cognition. Oxford: Blackwell, 1995.

TOSSELL, C. C.; KORTUM, P.; SHEPARD, C.; BARG-WALKOW, L. H.; RAHMATI, A.; ZHONG, L. A Longitudinal Study of Emoticon Use in Text Messaging from Smartphones. Computers in Human Behavior, v. 28, p. 659-663, 2012.

VANDERGRIFF, I. A Pragmatic Investigation of Emoticon Use in Nonnative Speaker/Native Speaker Text Chat.Language@Internet, v. 11.2014.

WALTHER, J. B.; D’ADDARIO, K. P. The Impacts of Emoticons on Message Interpretation in Computer-Mediated Communication. Social Science Computer Review, v. 19, n. 3, p. 324-347, 2001.

WHARTON, T. Pragmatics and Non-Verbal Communication. Cambridge: Cambridge University Press, 2009.

WICHMANN, A. The Attitudinal Effects of Prosody, and How They Relate to Emotion. In: ISCA

Workshop on Speech and Emotion: A Conceptual Framework for Research. Belfast, Queen's University, 2000 .

WISEMAN, R. What Boys Want. Time, 2-12-2013, 2013.

XU, L.; YI, C.; XU, Y. Emotional Expression Online: The Impact of Task, Relationship and Personality Perception on Emoticon Usage in Instant Messenger. In: 11th Pacific-Asia Conference on Information Systems. Auckland, 2007.

YUASA, M.; SAITO, K.; MUKAWA, N. Brain Activity when Reading Sentences and Emoticons: An fMRI Study of Verbal and Nonverbal Communication. Electronics and Communications in Japan, v. 94, n. 5, p. 17-24, 2011.

YUS, F. Ciberpragmática. El uso del lenguaje en Internet. Barcelona: Ariel, 2001.

. Attitudes and Emotions Through Written Text: The Case of Textual Deformation in Internet

Chat Rooms. Pragmalingüistica, v. 13, p. 147-174, 2005.

Saturación contextual en la comprensión de la ironía. In: RUIZ GURILLO, L.; PADILLA

GARCÍA, X. (Eds). Dime cómo ironizas y te diré quién eres: una aproximación pragmática a la ironía. Frankfurt: Peter Lang, 2009. p. 309-331. Ciberpragmática 2.0. Nuevos usos del lenguaje en Internet. Barcelona: Ariel, 2010. 2011. Cyberpragmatics. Internet-Mediated Communication in Context. Amsterdam: John Benjamins, Sociedad.

(forthcoming) El discurso de las identidades en línea: El caso de Facebook. Discurso \&

\section{Recebido em 30/04/14. Aprovado em 25/08/14.}

Título: Nem todos os emoticons são criados iguais

Autor: Francisco Yus

Resumo: O uso de deformação textual e de emoticons tornou-se um fenômeno difundido na comunicação mediada por computadores atual. Neste artigo, os emoticons são analisados a partir da perspectiva pragmática da Teoria da Relevância, o que implica determinar até que ponto eles contribuem para a eventual relevância da informação comunicada pelo texto digitado no teclado. Oito funções pragmáticas são propostas, correspondendo às diferentes formas pelas quais os emoticons satisfazem a busca pela relevância do usuário. A análise também irá abordar como emoticons contribuem para uma identificação mais detalhada de atitudes, sentimentos e emoções do usuário, que são, muitas vezes, de difícil definição em uma comunicação textual.

Palavras-chave: Emoticons. Deformação textual. Cyberpragmática. Oralidade. 
Título: No todos los emoticonos son creados iguales

Autor: Francisco Yus

Resumen: La deformación textual y el uso de emoticonos se ha extendido enormemente en la comunicación actual por ordenador. En este artículo, los emoticonos son analizados desde una perspectiva pragmática de corte relevantista, lo que conlleva determinar hasta qué punto los emoticonos contribuyen a la relevancia final de la información del texto tecleado en el teclado. Ocho funciones pragmáticas son propuestas, que corresponden a a las diferentes formas en las que los emoticonos satisfacen la búsqueda de relevancia del usuario. En el artículo también se analizará cómo los emoticonos contribuyen a una identificación más precisa de las actitudes, sentimientos y emociones del usuario, que a menudo son difíciles de determinar en la comunicación textual.

Palabras-clave: Emoticonos. Deformación textual. Ciberpragmática. Oralización. 